\title{
Kodeks Makarewicza w opiniach niemieckich autorów
}

\begin{abstract}
Mamy już dowód, że projekt robi wrażenie korzystne (wśród Niemców, a więc ludzi z pewnościq nie kierujacych się chęciq pisania uprzejmości w wersalskiej kurtuazji)

Juliusz Makarewicz, „Gazeta Administracji i Policji Państwowej” (1924)

Jest dla nas rzeczq bardzo ciekawa i interesujaca, jak oceniaja inne narody, szczególnie posiadajace odmienny światopoglad, nasz kodeks karny
\end{abstract} Jerzy Władysław Śliwowski, „Głos Sądownictwa” (1936)

\section{Uwagi wstępne}

Dierwszy polski nowoczesny kodeks karny z 11 lipca 1932 r. ${ }^{1}$ wzbo-

1 gacił się w ostatnim czasie o długo oczekiwaną monografię: pod redakcją sześciu naukowców z Katedry Prawa Karnego Katolickiego Uniwersytetu Lubelskiego Jana Pawła II, z panią profesor dr hab. Alicją Grześkowiak na czele, ukazało się zbiorowe opracowanie zatytułowane Kodeks karny z 1932 roku². Współautorzy przedstawili w nim kompleksową charakterystykę kodyfikacji, z uwzględnieniem jej genezy oraz rozwiązań części ogólnej i szczególnej.

Już w pierwszych zdaniach Wstępu do tej nowej monografii wyrażona została słuszna opinia o „wyjątkowym charakterze” kodeksu i jego oparciu na "najnowocześniejszych" koncepcjach doktrynalnych ${ }^{3}$. Wysoce

${ }^{1}$ Rozporządzenie Prezydenta Rzeczypospolitej z 11 lipca 1932 r. Kodeks karny, DzURP, 1932, nr 60, poz. 571.

${ }^{2}$ Wydawnictwo KUL, Lublin 2015.

${ }_{3}$,Wyjątkowy charakter tego kodeksu miał swoje źródło w tradycji polskiego prawa karnego. Wynikał on również z krytycyzmu wobec dominujących szkół i kierunków oraz 
pozytywną ocenę wyrazili też autorzy poszczególnych rozdziałów książ$\mathrm{ki}^{4}$. Identyczne stanowisko prezentowali i prezentują inni polscy karnicy ${ }^{5}$, jak również historycy prawa ${ }^{6}$.

Historycy prawa nie zdobyli się - jak dotąd - na syntetyczne czy choćby szersze omówienie kodeksu Makarewicza z perspektywy ich dziedziny. Wprawdzie nie brakuje przyczynków, m.in. pióra prof. Adama Lityńskiego ${ }^{7}$, prof. Józefa Koredczuka ${ }^{8}$, dr. Andrzeja Paska ${ }^{9}$ i innych autoró ${ }^{10}{ }^{10}$ lecz o obszerniejszym studium nie ma na razie mowy.

W tej sytuacji w niniejszym opracowaniu mogę tylko omówić kolejny aspekt kodyfikacji karnej z 1932 r. - właśnie z perspektywy historycznoprawnej. Wybrałam zagadnienie jak dotąd niezbadane - kwestię przyjęcia polskiego kodeksu na gruncie niemieckim, a w szczególności jego ocenę wyrażoną przez niemieckich autorów dwudziestolecia międzywojennego. Zamierzam odpowiedzieć na pytanie, jak niemieccy prawnicy wartościowali nasz kodeks i czy były to opinie jednolite. Na marginesie pragnę też poruszyć kwestię, czy na niemieckie postrzeganie polskiego kodeksu miała wpływ ideologia nazistowska.

z intelektualnej odwagi nakazującej »iść własną drogą«. Jednocześnie jednak w dużej mierze oparty był na najnowocześniejszych tendencjach występujących wówczas w ustawodawstwie europejskim", tamże, s. 7.

${ }^{4}$ Autor rozdziału pierwszego, poświęconego konstrukcji kodeksu i jego przepisów, prof. Tadeusz Bojarski z lubelskiego UMCS podkreśla, co następuje: „Wysuwał się on na czoło kodeksów europejskich tak pod względem założeń merytorycznych [...], jak też pod względem techniki legislacyjnej", tamże, s. 10.

${ }^{5}$ Por. „znaczący w skali europejskiej w ustawodawstwie karnym lat 30-tych”, T. Bojarski, Źródła prawa karnego, [w:] System prawa karnego, t. II, Warszawa 2011, s. 154; autor odsyła też do opinii wielu innych przedstawicieli współczesnej nauki prawa karnego. Por. „należał do najwybitniejszych osiągnięć legislacyjnych tego okresu w Europie”, A. Marek, Prawa karne, wyd. 10, Warszawa 2011, s. 18; przy czym autor tych słów odwołuje się do oceny wybitnego niemieckiego karnika Hansa-Heinricha Jeschcka - por. przyp. 61.

${ }^{6}$ Por.: "pod względem techniki ustawodawczej był dziełem nowoczesnym, wzorowanym na najlepszych osiągnięciach ówczesnej wiedzy", K. Sójka-Zielińska, Historia prawa, wyd. 15, Warszawa 2015, s. 275; „Należał do najlepszych ówczesnych kodeksów świata, a może nawet był najlepszy", S. Płaza, Historia prawa w Polsce na tle porównawczym: cz. 3, Okres międzywojenny, Kraków 2001, s. 381.

${ }^{7}$ Dwa kodeksy karne 1932 roku. W osiemdziesiata rocznice, „, Roczniki Administracji i Prawa, Wyższa Szkoła Humanistyczna" 2012, nr 12, s. 207-218.

${ }^{8}$ Znaczenie kodeksu karnego z 1932 r. dla rozwoju nauki i prawa karnego w Polsce w XX wie$k u$, „Zeszyty Prawnicze UKSW” 2011, t. XI, nr 2, s. 45-60.

${ }^{9}$ Kodeks karny z 1932 roku w opiniach autorów polskich, [w:] AUWr, nr 2620, Prawo, t. CCXC, Studia Historycznoprawne, Wrocław 2004, s. 297-306.

${ }^{10}$ Por. M. Wąsowicz, Juliusz Makarewicz - uczony i kodyfikator, „Studia Iuridica” 1993, nr 26, s. 111-131; A. Redzik, Profesor Juliusz Makarewicz - życie i dzieło, [w:] Prawo karne w poglądach Profesora Juliusza Makarewicza, red. A. Grześkowiak, Lublin 2005, s. 23-92. 


\section{Niemcy o kodeksie polskim}

Przed przystąpieniem do właściwych rozważań warto naświetlić problem znajomości bądź też dostępu niemieckich uczonych do kodeksu Makarewicza.

Już $\mathrm{w}$ toku prac kodyfikacyjnych na początku lat dwudziestych XX w. projekt części ogólnej kodeksu karnego został opublikowany po francusku, w ówczesnej lingua franca - wspólnym języku ludzi nauki ${ }^{11}$. Wkrótce potem ukazało się jego streszczenie niemieckie ${ }^{12}$ i wreszcie pełne tłumaczenie na język niemiecki (1928) ${ }^{13}$. Były to poczynania naturalne - $\mathrm{w}$ wielu krajach europejskich prowadzono w tym czasie podobne prace kodyfikacyjne, konsultowano je i oceniano publicznie w kraju i za granica, a krytyka naukowa była na porządku dziennym ${ }^{14}$.

Po wejściu w życie polski kodeks karny stał się znany za granicą dzięki swym przekładom na języki obce. Z pewnością były to znakomite przekłady - francuski został wydany przy współudziale francuskiego profesora i sędziego Jeana André Roux ${ }^{15}$. Pierwsze tłumaczenie na język niemiecki, autorstwa J. Makarewicza, który studiował w Niemczech i publikował liczne swoje prace po niemiecku, ukazało się w 1932 r. nakładem

${ }^{11}$ Projekt przygotowawczy części ogólnej kodeksu karnego [Tekst polski i ttumaczenie francuskie], [w:] Przeglad polskiego ustawodawstwa 1922, Warszawa 1922.

${ }^{12}$ Revue pénal suisse, 1922 (przekład Makarewicza).

${ }^{13}$ Der polnische Strafgesetzentwurf. Erster Teil, besorgt von J. Makarewicz, Lwów 1928, ss. 22. Por. sprawozdania zawarte w tomie: Komisja Kodyfikacyjna Rzeczypospolitej Polskiej, t. I, z. 11, Warszawa 1929, s. 330 i 352, dostępne w Internecie: http://www.bibliotekacyfrowa. pl/dlibra/plain-content?id=39728 [dostęp: 5.11.2015].

${ }^{14}$ Por. kilka przykładów opracowań polskich - z dawniejszych: S. Budziński, Poglad ogólny na prawodawstwa karne XIX-go wieku, "Gazeta Sądowa Warszawska" 1883, nr 4, s. 64-65; z dwudziestowiecznych: J. Reinhold, Środki zabezpieczajace przeciw niepoprawnym i anormalnym przestępcom, ze szczególnym uwzględnieniem nowych projektów kodeksów karnych, „Przegląd Prawa i Administracji” 1912, nr 37, s. 390-450; W. Makowski, Nowy Kodeks Karny Norweski, przekład postanowień szczegółowych i uwagi, [w:] Materiały do Kodyfikacji Prawa Karnego opracowane przez Sekcje Karna Towarzystwa Prawniczego w Warszawie, z. 1, Warszawa 1916, s. 171-174; S. Glaser, Prawo karne. Część ogólna. Na podstawie niemieckiej ustawy karnej z r. 1871, Warszawa 1920; tenże, Das neue polnische Strafgesetzbuch und die deutsche Strafrechtsreform, "Zeitschrift für Ostrecht” 1933, Bd. 7, s. 348-358. Normalną rzeczą były też polemiki - por. jedną z nich: J. Makarewicz, Randbemerkungen zum Strafgesetzentwurf, "Österreichische Zeitschrift für Strafrecht" 1910, Bd 1, s. 244-257 i odpowiedź von Gleispacha zamieszczoną w tym samym tomie czasopisma, s. 330-341.

${ }^{15}$ Code pénal polonais du 11 juillet 1932 et Loi sur les contraventions du 11 juillet 1932. Traduit sous la direction de M. Emile Stanislas Rappaport, par M. Conrad Berezowski, Paris 1933. Por. informacje o autorach przekładu: E. S. Rappaport, Wybrane zagadnienia nowoczesnej polityki kryminalnej (XX wieku), Łódź 1960, s. 47. 
Biura Pomocniczego Komisji Kodyfikacyjnej ${ }^{16}$. Zaraz potem wydano kodeks w zbiorze Polnische Gesetze und Verordnungen in deutscher Übersetzung (1932), a także w postaci osobnego druku (1933) $)^{17}$. Kolejne wydanie opublikowano znacznie później, na początku II wojny światowej, na zlecenie słynnego wrocławskiego Instytutu Europy Wschodniej. W ramach serii nazwanej „Zbiór ustaw polskich w przekładach niemieckich" ukazał się kodeks wraz z prawem wykroczeń i przepisami wprowadzającymi w tłumaczeniu i z wprowadzeniem Josefa Antona Chodzidlo ${ }^{18}$.

Polski kodeks wzbudził żywe zainteresowanie niemieckich uczonych już na etapie prac kodyfikacyjnych ${ }^{19}$. Nic dziwnego - interesowali się nim również inni badacze, a francuski profesor Pierre Garraud już w 1924 r. ogłosił pierwszą większą rozprawę na temat projektu polskiego kodeksu karnego ${ }^{20}$.

Po wejściu kodeksu w życie posypały się krótsze lub dłuższe recenzje, a nawet całe opracowania prezentujące i oceniające polską kodyfikację. Jedną z najwcześniejszych była opinia prawnika Heinricha Freunda, ogłoszona w 1933 r. na łamach wschodnioznawczego czasopisma „Osteuropa. Zeitschrift für die gesamten Fragen des Europäischen Ostens" ${ }^{\prime 2}$. Autor napisał obszerne sprawozdanie z rozwoju ustawodawstwa w II Rzeczypospolitej, oceniając także ustawodawstwo karne. Freund podkreślił przede wszystkim kompletny rezultat polskich prac kodyfikacyjnych - fakt uregulowania i procedury karnej, i prawa karnego materialnego, a tym samym zakończenia w 1932 r. „,budowy nowego gmachu wymiaru sprawiedliwości karnej" w Polsce ${ }^{22}$. Następnie recenzent wskazał, że kodeks oparto na zasadzie „odpowiedzialności moralnej” i karze, uwzględ-

${ }^{16}$ Das Strafgesetzbuch für die Republik Polen vom 11. Juli 1932, Verlag vom Hilfsarbeitenbüro der Kodifikationskommission, Warschau 1932. Niemiecki przekład spowodował, że kodeks rozpowszechnił się w innych krajach niemieckojęzycznych - por. E. D., Das Strafgesetzbuch für die Republik Polen vom 11. Juli 1932, „Schweizerische Zeitschrift für Strafrecht" 1933, Bd. 47, s. 143.

${ }^{17}$ Por. A. Schönke, Ausländisches Strafrecht. Übersicht über die wichtigsten Quellen und über das wichtigste Schrifttum, München-Berlin 1948, s. 32.

${ }^{18}$ Sammlung polnischer Gesetze in deutscher Übersetzung. Herausgegeben im Auftrage des Osteuropa-Instituts von Dr. Heinz Meyer, Berlin, Band 7: Das polnische Strafgesetzbuch mit der Verordnung betr. Übertretungen und den Einführungsvorschriften, Berlin 1940.

${ }^{19}$ Wskazał na to J. Makarewicz, Projekt polskiego kodeksu karnego, „Gazeta Administracji i Policji Państwowej” 1924, nr 1, s. 5. W sprawozdaniu znalazła się natomiast informacja o tym, że projekt części ogólnej był przedmiotem bacznej uwagi Francuzów, Szwajcarów i Austriaków, Komisja Kodyfikacyjna..., s. 33.

${ }^{20}$ Les Avant-projets polonais de 1922 sur la partie generale d'un code pénal, leur place dans le mouvement de reforme et de codification du droit pénal, Paris 1924, ss. 122.

${ }^{21} 15$ Jahre polnischer Rechtsentwicklung, "Osteuropa” 1932/1933, Bd. VIII, s. 530-541.

${ }^{22}$ Tamże, s. 540. 
niając jednocześnie $\mathrm{w}$ wielu rozwiązaniach zasadę zabezpieczenia społeczeństwa. Zdecydowanie pochwalił wyłączenie prawa wykroczeń do odrębnej ustawy i poddanie ich orzecznictwu władz administracyjnych, jednak z możliwością odwołania się do sądu. Aprobował system kar, a zwłaszcza ograniczenie krótkoterminowej kary pozbawienia wolności. Podkreślał szerokie ramy sankcji karnych oraz znaczną swobodę sędziowską przy wymierzaniu kar. W zakończeniu doszedł do wniosku: „W sumie nowy polski kodeks karny, wykazujący wiele punktów stycznych z nowym projektem niemieckim, nie jest wprawdzie hipernowoczesny, ale jednak uwzględnia nowoczesne postulaty w wystarczającym stopniu"23.

W końcu 1932 r. powstało obszerne sprawozdanie, niewolne od osobistych komentarzy, sporządzone przez Wenzeslausa Grafa Gleispacha, wiedeńskiego profesora i zaangażowanego, wybitnego legislatora austriackiego, a jednocześnie - zwolennika ruchu narodowosocjalistycznego $^{24}$. Ukazało się ono w berlińskim czasopiśmie "Zeitschrift für Ostrecht" w 1933 r., przy czym redakcja odnotowała w przypisie, że tekst wpłynął do druku na początku stycznia tego roku, a więc niespełna pół roku po wydaniu polskiego kodeksu ${ }^{25}$. Opracowanie Gleispacha było niezwykle fachowe i analityczne. Warto podkreślić, że pochodziło ono spod ręki autora, który przez trzydzieści lat brał czynny udział w pracach nad reformą prawa w Austrii, a nawet przedłożył własny projekt części ogólnej austriackiego kodeksu karnego. Nic dziwnego, że w kilku miejscach swej recenzji wiedeński uczony szukał zapożyczeń polskich legislatorów z projektu austriackiego z $1912 \mathrm{r}^{26}$

Gleispach zaprezentował całą materię prawnokarną kodeksu Makarewicza chłodno i rzeczowo, pochwały i reprymendy wygłaszając tylko sporadycznie. Chwalił formę wydania kodeksu, eksponując, że Polacy

${ }^{23}$ „Im ganzen genommen ist das neue polnische Strafrecht, das sehr viele Berührungspunkte mit dem neuen deutschen Entwurf aufweist, zwar nicht hypermodern, aber es hat den modernen Bestrebungen doch hinreichend Rechnung getragen", tamże, s. 541.

${ }^{24}$ Hrabia Gleispach pochodził z arystokratycznej rodziny austriackiej i do 1933 r. był profesorem Uniwersytetu w Wiedniu, a także bardzo aktywnym uczestnikiem prac kodyfikacyjnych nad austriackim prawem karnym; po przejściu na emeryturę przeniósł się do Berlina, gdzie wspierając nazistów rozwijał karierę, piastując m.in. stanowisko dziekana - por. A.-M. Gräfin von Lösch, Der nackte Geist. Die Juristische Fakultät der Berliner Universität im Umbruch von 1933, Tübingen 1999, s. 190-191.

${ }^{25}$ W. Gleispach, Das polnische Strafgesetzbuch, "Zeitschrift für Ostrecht” 1933, Nr. 7, s. 331-347 (przyp. na stronie 331). Czasopismo to powstało w 1927 r. z połączenia dwóch wcześniejszych periodyków: wrocławskiego (wydawanego przez słynny Osteuropa-Institut) oraz berlińskiego; ukazało się zaledwie osiem jego numerów (1927-1934).

${ }^{26}$ W. Gleispach, Das polnische..., s. 342, $344 \mathrm{i}$ in. 
uniknęli debaty parlamentarnej, która mogła „pokaleczyć” dzieło. Aprobował zwięzłość ujęcia przepisów, prostotę systemu kar, prawo karne nieletnich, konstrukcję środków zabezpieczających. Krytyce poddał niejasne - jego zdaniem - pojęcie winy oraz szeroki zakres dyskrecjonalnej władzy sędziowskiej, w tym brak wystarczających wskazówek dla sędziego dokonującego aktu wymiaru kary. Zwrócił uwagę na kilka usterek w porządku części szczególnej, akcentując ponadto, że niektóre przestępstwa nie zostały nazwane. Recenzję zakończył osobliwym podsumowaniem, pisząc: "Jeżeli wyobrazimy sobie dzieła ustawodawcze naszych czasów uporządkowane w długim szeregu, który zaczyna się włoskim kodeksem karnym, a kończy kodeksem Związku Sowieckiego, to polski kodeks karny jest na szczęście o wiele bliższy temu pierwszemu, niż temu ostatniemu" 27.

Obok Freunda i Gleispacha, polskiemu kodeksowi stosunkowo szybko przyjrzał się berliński profesor i sędzia Karl Klee, publikując zwięzłą jego ocenę w najstarszym, wydawanym od połowy XIX w. i bardzo ważnym czasopiśmie poświęconym prawu karnemu „Archiv für Strafrecht”"28.

Klee poświęcił uwagę zarówno części ogólnej, jak i (lecz pobieżnie) szczególnej kodeksu Makarewicza, oceniając jednak prezentowane rozwiązania wyłącznie z perspektywy niemieckiej. Pierwsza jego refleksja dotyczyła wprowadzenia w Polsce środków zabezpieczających, obok lub na miejsce kar pozbawienia wolności. Autor wskazywał, że rozwiązanie to „odpowiada w istocie ujęciu projektów niemieckiego i austriackiego", mając zapewne na myśli projekt niemiecki z 1930 r. ${ }^{29}$ Ponadto Klee porównał i ocenił charakter polskich przepisów dotyczących ścigania przestępstw popełnionych za granicą lub dokonanych przez cudzoziemców. Uczony uznał, że oparto je na „zasadzie ochrony i uniwersalności” („Schutzprinzip und Universalprinzip"), inaczej niż to zaproponowano w projekcie niemieckiego kodeksu karnego, który jego zdaniem osadzono na „zasa-

${ }^{27}$ Tamże, s. 347.

28 "Archiv für Strafrecht” 1933, Nr. 77, s. 154-155. Wskazane czasopismo ukazywało się pod tym tytułem od roku 1880; wcześniej było znane jako „Archiv für Gemeines Deutsches und für Preußisches Strafrecht” (1871-1879), a pierwotnie jako „Archiv für preußisches Strafrecht”, czyli „Goltdammer's Archiv für Strafrecht” (1853-1871).

${ }^{29}$ Zarówno projekt niemiecki z 1930 r., jak i poprzednie z lat 1927 i 1925, nawiązywały do tzw. projektu Radbrucha z 1922 r., który miał na celu upodobnienie prawa niemieckiego i austriackiego; po przejęciu władzy przez Hitlera, jeszcze w tym samym 1933 r., ogłoszono kolejny projekt, oparty na poprzednim z 1927 r. - por. T. Vormbaum, K. Rentrop (wyd.), Reform des Strafgesetzbuches. Sammlung der Reformentwürfe, Bd. 1, 1909 bis 1919; Bd. 2, 1922 bis 1939, Berlin 2008, passim. 
dzie światowego prawa karnego" („Weltstrafrechtsprinzip”) ${ }^{30}$. Recenzent zaakcentował też polską konstrukcję błędu co do prawa, podkreślając, że w Polsce usprawiedliwiony błąd mógł być podstawą nadzwyczajnego złagodzenia kary ${ }^{31}$, a ponadto polską postać usiłowania, wskazując na jego karanie na równi z dokonaniem. Klee wypunktował też fakt wyłączenia „przepisów policyjnych” (prawa wykroczeń) z treści prawa karnego. Podsumowując, autor napisał: „najnowszy polski kodeks karny w pełni odpowiada wyzwaniom, które należy stawiać nowoczesnemu ustawodawstwu karnemu" ${ }^{\prime 2}$.

Specyficzny charakter miała minirecenzja traktująca nie tyle o kodeksie karnym z 1932 r., co o opracowaniu na jego temat, które w 1933 r. opublikował w Niemczech prawnik pochodzący z Wilna, podpisujący się jako Gregor Wirschubski ${ }^{33}$. Niemiecki recenzent tej pracy, Walter Mannzen, szczególny nacisk położył na wprowadzenie w Polsce środków zabezpieczających, a zwłaszcza możliwości zamknięcia w zakładzie leczniczym sprawców niepoczytalnych. Recenzent cynicznie wskazał na ogromne znaczenie tego środka wobec faktu, iż - jego zdaniem - zamknięcia takiego miało wymagać 28 tysięcy chorych psychicznie Polaków ${ }^{34}$. Nie trzeba dodawać, że taka jednostronna opinia należała do rzadkości.

W 1936 r. na łamach znanego i mającego międzynarodowy charakter czasopisma "Zeitschrift für die gesamte Strafrechtswissenschaft" ukazało się obszerne, przeszło dwudziestostronicowe opracowanie Richarda Buscha, lipskiego sędziego i docenta, zatytułowane Kritische Bemerkungen zum polnischen Strafgesetzbuch ${ }^{35}$.

${ }^{30}$ Kodeks polski polecał karać (bez względu na obywatelstwo sprawcy) popełnione za granicą rozbójnictwo morskie, fałszowanie pieniędzy, handel niewolnikami, kobietami i dziećmi, przestępstwa niebezpieczne dla ogółu, handel narkotykami i pornografią oraz celowe użycie środka zdolnego do wywołania niebezpieczeństwa powszechnego, a ponadto przestępstwa przeciwko bezpieczeństwu Państwa Polskiego i jego urzędom.

31 Warto dodać, że kwestia ta była żywo dyskutowana również w Niemczech - por. S. Płaza, Historia prawa..., cz. 3, Okres międzywojenny, s. 412.

32 "Alles im allem ist zu sagen, dass das neuste Polnische StGB den Anforderungen, die an eine moderne Strafgesetzgebung zu stellen sind, vollauf entspricht", "Archiv für Strafrecht" 1933, Nr. 77, s. 155.

${ }^{33}$ Wirschubski ogłosił kilka prac na temat polskiej kodyfikacji, w tym przede wszystkim: Das polnische Strafgesetzbuch vom 11.7.1932 und die kriminalpolitischen Forderungen der Gegenwart, Dresden 1933, a następnie ten sam skondensowany tekst po polsku: Polski kodeks karny z 11 lipca 1932 r. a wymogi współczesnej polityki kryminalnej, „Wileński Przegląd Prawniczy" 1934, t. V, nr 3, s. 73-78; nr 4, s. 115-118.

${ }^{34}$ W. Mannzen [recenzja], Wirschubski Gregor, Das polnische Strafgesetzbuch vom 11.7.1932 und die kriminalpolitischen Forderungen der Gegenwart, Dresden 1933, „Monatsschrift für Kriminalpsychologie und Strafrechtsreform" 1933, Nr. 24, s. 766.

35 "Zeitschrift für die gesamte Strafrechtswissenschaft” 1936, Nr. 55, s. 621-641. 
Mimo tytułu głoszącego, że chodzi o „krytyczne uwagi do polskiego kodeksu karnego", recenzja Buscha miała raczej polemiczny charakter i moim zdaniem mieściła się całkowicie $w$ granicach ówczesnego dyskursu naukowego. Autor z dużym znawstwem prezentował polskie rozwiązania, rzadko je podważając, częściej natomiast porównując z innymi kodeksami czy projektami ustawodawczymi, głównie Niemiec, Francji i Włoch. Jego recenzja miała w dużej mierze pozytywny wydźwięk, a polemika dotyczyła wybranych konstrukcji teoretycznych nowej polskiej kodyfikacji ${ }^{36}$.

Busch podkreślił na wstępie, że polski kodeks karny był „nie tylko nowy, ale i własny" ${ }^{\prime 37}$. Autor stwierdził, że na jego kształt wpłynęły "główne idee powszechnego europejskiego ruchu reformatorskiego zmierzającego do skutecznego zwalczania przestępczości - w zakresie regulacji skutków przestępstw; dogmatyka niemieckich projektów z lat 1927 i 1930 - w zakresie ujęcia ogólnych przepisów o przestępstwie; zasady opracowane przez Association Internationale de Droit pénal, dotyczące upodobnienia poszczególnych narodowych porządków prawa karnego (tzw. międzynarodowego prawa karnego)"38. Jednocześnie zasadniczo odciął się od opinii wspomnianego już wyżej Grafa Gleispacha, który niedwuznacznie oceniał, że nowy polski kodeks karny mógł powstać równie dobrze $\mathrm{w}$ jakimkolwiek innym miejscu Europy ${ }^{39}$. Busch z naciskiem zaznaczył, że wniosek na temat narodowego, polskiego charakteru kodeksu można byłoby wysnuć dopiero po dokładnym zbadaniu charakteru narodowego Polaków, tymczasem kodyfikacja „idzie w wielu kwestiach własną drogą"40.

Następnie Busch rozpatrzył charakter polskiego kodeksu karnego ze specyficznej, częściowo historycznej już perspektywy: postanowił zbadać, czy polskie rozwiązania należą do tzw. prawa karnego woli (Willensstrafrecht),

\footnotetext{
${ }^{36}$ Opracowanie Buscha doczekało się recenzji ze strony młodego polskiego karnisty, absolwenta Uniwersytetu Warszawskiego J. W. Śliwowskiego, Kodeks Karny Polski w opinji [sic!] obcych, "Głos Sądownictwa” 1936, t. VIII, nr 7-8, s. 593-595. Recenzent z uwagą odnotował najważniejsze zarzuty niemieckiego uczonego, z niektórymi polemizując. Moim zdaniem i niemieckie opracowanie, i jego polska recenzja były typowymi przykładami ówczesnej polemiki naukowej w dziedzinie prawa karnego.

${ }^{37}$ „nicht nur ein neues, sondern zum ersten Male wieder seit etwa 200 Jahren ein eigenes Strafrecht”, R. Busch, Kritische Bemerkungen zum polnischen Strafgesetzbuch, "Zeitschrift für die gesamte Strafrechtswissenschaft" 1936, Nr. 55, s. 621.

${ }^{38}$ Tamże, s. 621-622.

39 „Wir haben ein Werk vor uns, das uns nicht an Polen gebunden erscheint, wie ein Vergleich mit Gesetzen und Entwürfen erweisen würde, die im letzten Jahrzehnt im europäischen Raum da und dort erschienen sind", W. Gleispach, Das polnische..., s. 332.

${ }^{40}$ "das polnische Strafgesetzbuch geht in vielen Fragen eigene Wege", R. Busch, Kritische Bemerkungen..., s. 622.
} 
czy raczej do prawa karnego wynikowego (Erfolgsstrafrecht $)^{41}$. Pod tymi pojęciami kryła się, ogólnie rzecz ujmując, z jednej strony zasada subiektywizmu odpowiedzialności karnej, z drugiej - obiektywizmu tej odpowiedzialności.

Pierwszym przytoczonym i przeanalizowanym przez autora przykładem „prawa karnego woli” była polska konstrukcja usiłowania, dla której wzorem mogły być, zdaniem Buscha, projekty niemieckie z lat 1927 i $1930^{42}$ lub też wskazówki Association Internationale de Droit penal ${ }^{43}$. Autor wywodził, że usiłowanie można określać tylko z subiektywnego punktu widzenia sprawcy, wskazywał na różnicę między usiłowaniem a (niekaralnym $\mathrm{w}$ prawie polskim) przygotowaniem do przestępstwa, a także na karalność usiłowania w granicach przewidzianych dla danego przestępstwa. Porównywał polskie rozwiązania z włoskimi ${ }^{44}$ i francuskimi ${ }^{45}$, dochodząc ponownie do wniosku, że są one najbardziej zbliżone do niemieckich ${ }^{46}$.

Następnie Busch skupił uwagę na polskiej koncepcji przestępnego współdziałania. Podkreślił, że pomocnicy odpowiadali jak za usiłowanie i zasadniczo nie korzystali z nadzwyczajnego złagodzenia kary, co różniło polskie rozwiązania od zachodnioeuropejskich ${ }^{47}$.

Należy zaznaczyć, że recenzent, analizując przepisy o karalności usiłowania i współdziałania przestępnego, wyraził przekonanie, że polski ustawodawca położył główny akcent na subiektywnej stronie dokonywanego przestępstwa, innymi słowy - rozwiązania polskie miały nastawienie subiektywne i jako takie mieściły się we wskazanym, tzw. prawie karnym woli. Analogiczną notę wystawił recenzent polskim przepisom dotyczącym odpowiedzialności sprawców częściowo niepoczytalnych, działających pod wpływem alkoholu, recydywistów, przestępców zawodowych i nałogowych ${ }^{48}$.

${ }^{41}$ Por. J. W. Śliwowski, Kodeks Karny..., s. 593.

${ }^{42}$ Por. przyp. 29.

${ }^{43} \mathrm{Na}$ temat tego francuskiego stowarzyszenia, powstałego po I wojnie światowej w wyniku rozłamu w dawnym Międzynarodowym Związku Kryminalistycznym - por. P. Cornil, Betrachtungen zum 50-jährigen Bestehen der Association Internationale de Droit Pénal, „Zeitschrift für die gesamte Strafrechtswissenschaft" 1975, Nr. 87, s. 438-457.

${ }^{44}$ Kodeks karny włoski z 19 XI 1930 r. wszedł w życie z dniem 1 VII 1931 r. - por. jego dwujęzyczne wydanie: Das italienische Strafgesetzbuch vom 19. Oktober $1930<$ Königl. Dekret Nr. 1398> = Il Codice penale Italiano <regio decreto 19 ottobre 1930 n. 1398>, übersetzt und mit einer Einführung, Anmerkungen, einem Sachverzeichnis und einer Vergleichstabelle versehen von R. Riz, Berlin 1969.

${ }^{45}$ Projekt francuski z 1933 r. miał charakter eklektyczny i uwzględniał osiągnięcia nowszych kodeksów karnych (chociaż nie polskiego), lecz nie wszedł w życie; por. S. Płaza, Historia prawa..., cz. 3, Okres międzywojenny ..., s. 352-353.

${ }^{46}$ R. Busch, Kritische Bemerkungen..., s. 626.

${ }^{47}$ Tamże, s. 627.

${ }^{48}$ Tamże, s. 628. 
W dalszej kolejności Busch skierował uwagę ku polskiej definicji przestępstwa, którą uznał za opartą na formalnym pojęciu bezprawności, podobnie jak to rozwiązano w kodeksie włoskim i projekcie francuskim. Zdaniem recenzenta kodyfikacja polska była wyrazem uznania przez państwo, że karalne są tylko czyny zabronione przez ustawę, a sędziego należy ściśle związać ustawa gdy chodzi o uznanie, kto podlega karze. Jednocześnie Busch z góry zauważył, że to silne skrępowanie sędziego zostało "osłabione" przez daleko idącą rezygnację w części szczególnej z kwalifikowanych i uprzywilejowanych postaci przestępstw oraz przekazanie sędziom wyjątkowo szerokiej władzy w zakresie wymiaru kary ${ }^{49}$. Do tego wątku wrócił jeszcze kilkakrotnie.

Baczną uwagę poświęcił niemiecki uczony zagadnieniu błędu sprawcy czynu zabronionego. Busch krytycznie omówił polską regulację dotyczącą błędu, podkreślając, że zabrakło w niej jasnego rozróżnienia między błędami co do faktu i co do prawa. Podkreślił brak możliwości uwolnienia od kary sprawcy działającego pod wpływem błędu, co jego zdaniem zbliżało rozwiązania polskie do włoskich ${ }^{50}$.

Uznania niemieckiego recenzenta nie znalazły też polskie regulacje dotyczące obrony koniecznej i stanu wyższej konieczności. Busch odnotował, że są one takie same jak w kodeksie włoskim, lecz zbyt lakoniczne, a zatem niejasne pod względem dogmatycznym i nieprzystosowane do praktycznego stosowania ${ }^{51}$.

Szeroko omówił natomiast Busch przyjęty w Polsce system kar. Co do kary śmierci podkreślił, że występuje ona zawsze jako alternatywne zagrożenie $z$ karą więzienia, przy czym rozwiązanie to uznał generalnie za słuszne $\mathrm{z}$ uwagi na charakter polskich przepisów dotyczących zabójstwa ${ }^{52}$. Zaakcentował, że centralną rolę w polskim systemie zajęła kara pozbawienia wolności, występująca tylko w dwóch elementarnych formach: więzienia i aresztu. Przeciwstawił ten model projektowi francuskiemu, w którym wyodrębniono kilka rodzajów kar na wolności. Wreszcie ocenił polskie rozwiązanie, wskazując, że będzie ono prowadzić nieuniknienie do zniwelowania oceny przestępstw. Niemiecki uczony chętnie widziałby inne wyjście pozwalające karać mordercę czy zdrajcę ojczyzny surowiej niż sprawcę nieumyślnego zabój-

${ }^{49}$ Tamże, s. 630. Autor przeciwstawił polskie rozwiązania - regulacji włoskiej.

${ }^{50}$ Tamże, s. 630-631. Busch wprost polemizował z opinią Makarewicza na temat interpretacji art. 20 polskiego kodeksu karnego.

${ }^{51}$ Tamże, s. 633.

${ }^{52}$ Polski kodeks nie wyróżniał morderstwa ani innych kwalifikowanych form zabójstwa. 
stwa albo ciężkiego uszkodzenia ciała. Powoływał się przy tym na wymogi polityki kryminalnej i, oczywiście, ówczesny projekt niemiecki ${ }^{53}$.

Sporo uwagi poświęcił Busch karom dodatkowym, a zwłaszcza pozbawieniu prawa wykonywania zawodu, przepadkowi przedmiotów pochodzących z przestępstwa i narzędzi przestępstwa oraz ogłoszeniu wyroku w piśmie. Podkreślił, że te i pozostałe kary dodatkowe nie występują w Polsce automatycznie, jako skutki skazania, lecz są orzekane w wyroku - obligatoryjnie lub fakultatywnie. To różniło kodeks polski od włoskiego oraz projektu francuskiego. Jednocześnie recenzent oceniał, iż w Polsce kary dodatkowe, a w szczególności utrata prawa wykonywania zawodu, mają raczej charakter środków zabezpieczających, ponieważ ich celem jest zabezpieczenie społeczeństwa przed przyszłymi czynami karygodnymi ze strony określonych sprawców ${ }^{54}$. Ostatnią kara, którą zajął się bliżej niemiecki uczony, było ogłoszenie wyroku w piśmie. Busch ganił polskie przepisy jako niewystarczające i przeciwstawiał im rozwiązania włoskie oraz projekty francuski i niemiecki, przewidujące upublicznianie wyroków skazujących w dużo szerszym wymiarze. Autor uważał, że wielorakie obwieszczanie orzeczeń sądów karnych dobrze służy celom prewencji ogólnej ${ }^{55}$.

Co do środków zabezpieczających, Busch przekonywał, że polskie rozwiązania najbardziej przypominają projekt niemiecki i są lepsze niż włoskie czy francuskie. Akcentował większą swobodę polskich sędziów, $\mathrm{w}$ porównaniu $\mathrm{z}$ ich zachodnioeuropejskimi kolegami, $\mathrm{w}$ zarządzaniu środków zabezpieczających. Nie pochwalił natomiast przyjęcia koncepcji „niebezpieczeństwa dla porządku prawnego" jako kryterium ich stosowania; zamiast niego chętnie poleciłby niemiecki wyznacznik w postaci „zagrożenia dla bezpieczeństwa publicznego". Odnotował też brak w polskiej kodyfikacji definicji przestępcy zawodowego i nałogowego, który - jego zdaniem - musiał prowadzić do niestosowania przez sędziów środków zabezpieczających wobec tych kategorii sprawców przy pierwszym skazaniu ${ }^{56}$.

Odpowiedzialność nieletnich również zajęła uwagę niemieckiego uczonego, który przede wszystkim wyeksponował wychowawczy charakter środków stosowanych w Polsce wobec tej kategorii sprawców.

${ }^{53}$ R. Busch, Kritische Bemerkungen..., s. 635. Co ciekawe, polski recenzent opracowania Buscha zgodził się z tym zarzutem, por. J. W. Śliwowski, Kodeks Karny..., s. 594 in fine.

${ }^{54}$ R. Busch, Kritische Bemerkungen..., s. 635-637.

${ }^{55}$ Tamże, s. 637. Autor polecał - za wzorami włoskim i francuskim - ogłoszenie wyroku w miejscu jego wydania, a ponadto $\mathrm{w}$ miejscu popełnienia przestępstwa i ostatniego zamieszkania sprawcy.

${ }^{56}$ Tamże, s. 638-639. Polski recenzent opracowania Buscha całkowicie popierał obawy niemieckie - por. J. W. Śliwowski, Kodeks Karny..., s. 595. 
Autor akceptował takie rozwiązanie, preferując jednak projekt niemiecki, w którym upoważniono sędziów do wyboru między środkami wychowawczymi a karą złagodzoną wobec nieletniego.

Ostatnim zagadnieniem skomentowanym przez Buscha był zakres swobody polskiego sędziego. Niemiecki uczony powtórzył, że polski ustawodawca zrezygnował z unormowania wielu znamion czynów kwalifikowanych i uprzywilejowanych oraz pochwalił to dążenie do syntetyczności kodeksu karnego. Jednocześnie wskazał, że sędziowie korzystają w Polsce nie tylko z szerokich ram kary, lecz dysponują ponadto możliwościami nadzwyczajnego złagodzenia kary, a oprócz tego decydują o warunkowym zawieszeniu wykonania kary, warunkowym zwolnieniu z odbycia jej części, nie mówiąc już o orzekaniu środków wychowawczych lub zakładu poprawczego względem nieletnich oraz o czasie trwania środków zabezpieczających. Autor zachwalał takie rozwiązanie, wskazując na jego podobieństwo do projektu niemieckiego, lecz jednocześnie wyraził obawę o jego praktyczne wykorzystywanie, a to ze względu na zupełny brak wytycznych „światopoglądowych" (ideologicznych) dla wykładni i stosowania prawa karnego w Polsce. Wolno przypuszczać, że ten niepokój wynikał z warunków, w jakich działał recenzent - otoczenia ideologicznego III Rzeszy. W przeanalizowanej recenzji był to jednak właściwie jedyny widoczny ślad wpływu doktryny nazistowskiej na sposób myślenia niemieckiego uczonego ${ }^{57}$.

Po II wojnie światowej kodeks Makarewicza nadal cieszył się przychylną opinią $w$ Niemczech ${ }^{58}$. Niektórzy uczeni niemieccy piszący w drugiej połowie XX w. zaczęli wskazywać, moim zdaniem słusznie, że polski kodeks nie czerpał z koncepcji niemieckich czy austriackich, lecz ze szwajcarskiego prawa karnego ${ }^{59}$. Nikt nie rozwiną jednak szerzej tego wątku ${ }^{60}$.

${ }^{57} \mathrm{O}$ dystansie Buscha wobec skrajnych opinii świadczy również jego negatywne ustosunkowanie się do opinii Gleispacha, o czym była mowa wyżej - por. przyp. 39-40.

${ }_{58}$ Por. przekonanie urodzonego w Polsce a działającego w Niemczech L. Frendla: „StGB vom 11.7.1932, das seinerzeit auch im Westen als modernes Gesetzeswerk hoch angesehen und geschätzt wurde” („KK z 11.7.1932, który jako nowoczesne dzieło ustawodawcze był w jego czasach wysoko stawiany i ceniony także na Zachodzie"), L. Frendl, Die Strafe im Entwurf des polnischen Strafgesetzbuches, "Jahrbuch für Ostrecht" 1968, Bd. IX, Nr. 2, s. 110.

${ }^{59}$ R. Schnur, profesor prawa publicznego z Tybingi, znawca i recenzent polskiego prawa, w zwięzłym opracowaniu o wpływach prawa niemieckiego i austriackiego w Polsce jasno wyłożył, że „Nowy kodeks karny był zorientowany przede wszystkim na szwajcarskie prawo karne" - por. R. Schnur, Einflüsse des deutschen und österreichischen Rechts in Polen, [w:] Schriftenreihe der Juristischen Gesellschaft zu Berlin, Hf. 95, Berlin-New York 1985, s. 17.

${ }^{60}$ Warto przypomnieć $\mathrm{w}$ tym miejscu, że pierwszy projekt szwajcarskiego kodeksu karnego, autorstwa wybitnego prawnika Karla Stoossa, powstał już w 1894 r.; potem 
Pogląd o nieprzeciętnych walorach kodeksu Makarewicza utrwalił w niemieckiej literaturze prawniczej profesor Hans-Heinrich Jescheck, wybitny znawca prawa karnego, autor wielu podręczników akademickich, długoletni dyrektor Instytutu Krajowego i Międzynarodowego Prawa Karnego im. Maksa Plancka we Fryburgu Brygowijskim. W drugiej połowie lat siedemdziesiątych XX w. napisał on, że „polski kodeks karny z 1932 r. zaliczał się do najlepszych osiągnięć nowszego ustawodawstwa karnego w Europie" ${ }^{\prime 61}$. Jego opinia przesądziła o zapatrywaniach wielu innych prawników zarówno niemieckich, jak i polskich ${ }^{62}$.

\section{Podsumowanie}

Stanowisko niemieckich uczonych wobec kodeksu Makarewicza było pozytywne i konkretne, chociaż nie zawsze bezstronne. Większość Niemców, mistrzów filozofii i doktryny prawa, nie roztrząsała w zasadzie podbudowy światopoglądowej polskiej kodyfikacji. Nie szukała też w kodeksie odpowiedzi na fundamentalne pytania o istotę i sens kary, wolną wolę człowieka czy źródła przestępczości - tematy tak chętnie i wszechstronnie dyskutowane w ówczesnej doktrynie. Tylko nieliczni uczeni postrzegali konstrukcje nowego prawa karnego w Polsce przez pryzmat ideologii nazistowskiej.

Niemcy oceniali konkretne regulacje kodeksowe, wartościując poszczególne rozwiązania dość precyzyjnie i polemicznie. Nie podkreślali zasad gwarancyjnych polskiego prawa karnego, natomiast dostrzegali i przyzwalali na formalną definicję przestępstwa. Akcentowali, że Polacy zrezygnowali z klasycznego trójpodziału przestępstw poprzez wyłączenie wykroczeń z prawa karnego, w pełni aprobując tę systematykę. Odnotowywali przepisy świadczące o subiektywizmie odpowiedzialności karnej w Polsce, podkreślając zwłaszcza nowatorskie elementy instytucji

opracowano kolejne, najważniejszy zaś (rządowy) w 1918 r. Został on przedyskutowany w parlamencie, przerobiony i ostatecznie wydany jako projekt z $1931 \mathrm{r}$, a następnie uchwalony w 1937 r. i przyjęty w referendum w 1938 r.; kodeks wszedł w życie w 1942 r. Por. S. Płaza, Historia prawa..., cz. 3, Okres międzywojenny..., s. 366-367. Por. też D. Janicka, Makarewicz a Liszt. Próba analizy porównawczej, CPH, 2015, t. LXVII, z. 1, s. 107-128; tejże, Niebezpieczny przestępca w doktrynie prawa karnego przełomu XIX/XX w., [w:] Kuba rozpruwacz i inni, red. V. Kwiatkowska-Wójcikiewicz, Toruń 2015, s. 9-32.

${ }^{61}$ „(zählte) zu den besten Leistungen der neueren Strafgesetzgebung in Europa", H. H. Jescheck, Das neue deutsche Strafrecht im Vergleich mit dem polnischen Recht, "Zeitschrift für die gesamte Strafrechtswissenschaft" 1976, Nr. 88, s. 467.

${ }^{62}$ Por. przyp. 5. 
usiłowania i współdziałania przestępnego, chociaż nie zawsze się z nimi zgadzali. Chwalili przyjęte w Polsce środki karne, a w szczególności całkowicie nowe środki zabezpieczające. Komplementowali wyeliminowanie krótkoterminowych kar pozbawienia wolności. Za naturalne i korzystne uznawali specjalne przepisy karne względem nieletnich.

Niemieccy specjaliści podkreślali, że polskie dzieło kodyfikacyjne jest syntetyczne, samodzielne i odpowiadające wymaganiom współczesności.

\section{Bibliografia}

\section{Źródła}

Code pénal polonais du 11 juillet 1932 et Loi sur les contraventions du 11 juillet 1932. Traduit sous la direction de M. Emile Stanislas Rappaport, par M. Conrad Berezowski, Paris 1933.

D. E., Das Strafgesetzbuch für die Republik Polen vom 11. Juli 1932, „Schweizerische Zeitschrift für Strafrecht" 1933, Nr. 47.

Das italienische Strafgesetzbuch vom 19. Oktober $1930<$ <önigl. Dekret Nr. 1398> = Il Codice penale Italiano <regio decreto 19 ottobre 1930 n. 1398>, übersetzt und mit einer Einführung, Anmerkungen, einem Sachverzeichnis und einer Vergleichstabelle versehen von R. Riz, Berlin 1969.

514 Komisja Kodyfikacyjna Rzeczypospolitej Polskiej, t. I, z. 11, Warszawa 1929, http:// www.bibliotekacyfrowa.pl/dlibra/plain-content?id=39728 [dostęp: 5.11.2015].

Der polnische Strafgesetzentwurf. Erster Teil, besorgt von J. Makarewicz, Lwów 1928.

Projekt przygotowawczy części ogólnej kodeksu karnego [Tekst polski i ttumaczenie francuskie], [w:] Przeglad polskiego ustawodawstwa 1922, Warszawa 1922.

Revue pénal suisse, 1922.

Rozporządzenie Prezydenta Rzeczypospolitej z 11 lipca 1932 r. Kodeks karny, DzURP, 1932, nr 60, poz. 571.

Sammlung polnischer Gesetze in deutscher Übersetzung. Herausgegeben im Auftrage des Osteuropa-Instituts von Dr. Heinz Meyer, Berlin, Band 7: Das polnische Strafgesetzbuch mit der Verordnung betr. Übertretungen und den Einführungsvorschriften, Berlin 1940.

Das Strafgesetzbuch für die Republik Polen vom 11. Juli 1932, Verlag vom Hilfsarbeitenbüro der Kodifikationskommission, Warschau 1932.

\section{Opracowania}

Bojarski T., Źródła prawa karnego, [w:] System prawa karnego, t. II, Warszawa 2011. Budziński S., Poglad ogólny na prawodawstwa karne XIX-go wieku, „Gazeta Sądowa Warszawska" 1883, nr 4.

Busch R., Kritische Bemerkungen zum polnischen Strafgesetzbuch, „Zeitschrift für die gesamte Strafrechtswissenschaft" 1936, Nr. 55.

Cornil P., Betrachtungen zum 50-jährigen Bestehen der Association Internationale de Droit Pénal, „Zeitschrift für die gesamte Strafrechtswissenschaft” 1975, Nr 87. 
Frendl L., Die Strafe im Entwurf des polnischen Strafgesetzbuches, „Jahrbuch für Ostrecht" 1968, Bd. IX, Nr. 2.

Freund H., 15 Jahre polnischer Rechtsentwicklung, „Osteuropa. Zeitschrift für die gesamten Fragen des Europäischen Ostens" 1932/1933, Bd. VIII.

Garraud P., Les Avant-projets polonais de 1922 sur la partie generale d'un code pénal, leur place dans le mouvement de reforme et de codification du droit pénal, Paris 1924.

Glaser S., Das neue polnische Strafgesetzbuch und die deutsche Strafrechtsreform, „Zeitschrift für Ostrecht" 1933, Bd. 7.

Glaser S., Prawo karne. Część ogólna. Na podstawie niemieckiej ustawy karnej z r. 1871, Warszawa 1920.

Gleispach W., Das polnische Strafgesetzbuch, "Zeitschrift für Ostrecht” 1933, Bd. 7. Gräfin von Lösch A.-M., Der nackte Geist. Die Juristische Fakultät der Berliner Universität im Umbruch von 1933, Tübingen 1999.

Janicka D., Makarewicz a Liszt. Próba analizy porównawczej, CPH, 2015, t. LXVII, z. 1. Janicka D., Niebezpieczny przestepca w doktrynie prawa karnego przełomu XIX/XX w., [w:] Kuba rozpruwacz i inni, red. V. Kwiatkowska-Wójcikiewicz, Torun 2015.

Jescheck H. H., Das neue deutsche Strafrecht im Vergleich mit dem polnischen Recht, „Zeitschrift für die gesamte Strafrechtswissenschaft” 1976, Bd. 88.

Klee K., Das Strafgesetz für die Republik Polen vom 11. Juli 1932, deutsch übersetzt, Warschau 1932, „Archiv für Strafrecht” 1933, Nr. 77.

Kodeks karny z 1932 roku, red. A. Grześkowiak, Lublin 2015.

Koredczuk J., Znaczenie kodeksu karnego z 1932 r. dla rozwoju nauki i prawa karnego w Polsce w XX wieku, "Zeszyty Prawnicze UKSW" 2011, t. XI, nr 2.

Lityński A., Dwa kodeksy karne 1932 roku. W osiemdziesiąta rocznice, "Roczniki Administracji i Prawa, Wyższa Szkoła Humanistyczna" 2012, nr 12.

Makarewicz J., Projekt polskiego kodeksu karnego, „Gazeta Administracji i Policji Państwowej" 1924, nr 1.

Makarewicz J., Randbemerkungen zum Strafgesetzentwurf, „Österreichische Zeitschrift für Strafrecht" 1910, Nr. 1.

Makowski W., Nowy Kodeks Karny Norweski, przekład postanowień szczegółowych i uwagi, [w:] Materiaty do Kodyfikacji Prawa Karnego opracowane przez Sekcje Karna Towarzystwa Prawniczego w Warszawie, z. 1, Warszawa 1916.

Mannzen W. [recenzja], Wirschubski Gregor, Das polnische Strafgesetzbuch vom 11.7.1932 und die kriminalpolitischen Forderungen der Gegenwart, Dresden 1933, „Monatsschrift für Kriminalpsychologie und Strafrechtsreform” 1933, Nr. 24.

Marek A., Prawa karne, wyd. 10, Warszawa 2011.

Pasek A., Kodeks karny z 1932 roku w opiniach autorów polskich, [w:] AUWr, nr 2620, Prawo, t. CCXC, Studia Historycznoprawne, Wrocław 2004.

Płaza S., Historia prawa w Polsce na tle porównawczym, cz. 3. Okres międzywojenny, Kraków 2001.

Rappaport E. S., Wybrane zagadnienia nowoczesnej polityki kryminalnej (XX wieku), Łódź 1960.

Redzik A., Profesor Juliusz Makarewicz - życie i dzieło, [w:] Prawo karne w pogladach Profesora Juliusza Makarewicza, red. A. Grześkowiak, Lublin 2005. 
Reinhold J., Środki zabezpieczające przecizw niepoprawnym i anormalnym przestępcom, ze szczególnym uwzględnieniem nowych projektów kodeksów karnych, „Przegląd Prawa i Administracji" 1912, nr 37.

Schnur R., Einflüsse des deutschen und österreichischen Rechts in Polen, [w:] Schriftenreihe der Juristischen Gesellschaft zu Berlin, Hf. 95, Berlin-New York 1985.

Schönke A., Ausländisches Strafrecht. Übersicht über die wichtigsten Quellen und über das wichtigste Schrifttum, München-Berlin 1948.

Sójka-Zielińska K., Historia prawa, wyd. 15, Warszawa 2015.

Śliwowski J. W., Kodeks Karny Polski w opinji [sic!] obcych, "Głos Sądownictwa" 1936, t. VIII, nr 7-8.

Vormbaum T., Rentrop K. (wyd.), Reform des Strafgesetzbuches. Sammlung der Reformentwürfe, Bd. 1, 1909 bis 1919, Bd. 2, 1922 bis 1939, Berlin 2008.

Wąsowicz M., Juliusz Makarewicz - uczony i kodyfikator, „Studia Iuridica” 1993, nr 26.

Wirschubski G., Das polnische Strafgesetzbuch vom 11.7.1932 und die kriminalpolitischen Forderungen der Gegenwart, Dresden 1933.

Wirschubski G., Polski kodeks karny z 11 lipca 1932 r. a wymogi wspótczesnej polityki kryminalnej, „Wileński Przegląd Prawniczy” 1934, t. V, nr 3, s. 73-78; nr 4. 